Egey, E. (2021). Fordítói dilemmák a Magyar Táncmúvészeti Egyetemen. Tánc és Nevelés.

Dance and Education, 2(2), 31-44., DOI: https: / / doi.org/10.46819/TN.2.2.31-44

\title{
FORDÍTÓI DILEMMÁK A MAGYAR TÁNCMÚVÉSZETI EGYETEMEN
}

\author{
Egey Emese PhD, egyetemi docens és nyelvtanár, \\ Magyar Táncmúvészeti Egyetem, Pedagógia és Pszichológia Tanszék
}

\begin{abstract}
Absztrakt
A Magyar Táncmúvészeti Egyetemen keletkező és angol nyelvre fordítandó dokumentumok mennyisége folyamatosan nô. Jelen írás röviden vázolja a fordítástudomány mint önálló tudományterület néhány alapelvét és kutatási eredményét, valamint bemutat néhány fordításetikai és fordítástechnikai kérdést. Az egyetemi szövegekbőll vett számos példával érzékelteti, milyen kihívásokat jelent általában a fordítás, a terminológia alkotás. Részletesen tárgyalja a fordítás nyelvi ellenőrzésének szükségességét és indokolja, miért lehet fontos már a forrásnyelvi szöveg korrektúrája is. Javaslatot tesz fordítói munkacsoport mielóbbi tényleges létrehozására.
\end{abstract}

Kulcsszavak: barátságtalan nyelvpárok, terminológiai kérdések, forrás- és célnyelvi ellenőrzés

\section{BEVEZETÉS}

A Magyar Táncmúvészeti Egyetem (továbbiakban MTE) nyelvtanár oktatójaként az elmúlt tanévekben részbeni, az utóbbi idôben fő tevékenységként feladatom hivatalos írott szövegek magyarról angolra fordítása. A kérdéses szövegek kisebb része jogi természetú (szerződések, szabályzatok), hivatalos (belső) irat (rektori körlevelek, szakmai pályázati anyagok, szülői hozzájárulások orvosi vizsgálatokhoz, szakdolgozati követelményrendszer és útmutató). Túlnyomó többségük a táncos szakmához kapcsolódó, ugyanakkor inkább hivatalos jellegú szöveg (tanszéki ismertetốk, konferencia kötetek absztraktjai), szakcikk (a kétnyelvú Tánc és Nevelés címú folyóirat számára), illetve legnagyobb számban a honlap számára készülő szakmai önéletrajz.

Úgy vélem, hogy ezek az utóbbi években terítékre került szövegek, amint azt a példákkal illusztrálni is kívánom, nem elsősorban a szorosan vett táncterminológia területéhez tartoznak. Ezért írásom nem a táncterminológia története vagy jelen helyzetének elemzése, bár a témával szükségszerúen átfedést mutat. Sokkal inkább a táncmúvész és táncpedagógus képzés, valamint az MTE mint intézmény és munkáltató mindennapi életéből adódó egyéb fordítási kihívásokat, azok lehetséges megoldásait veszi sorba. Ehhez elengedhetetlen a fordítástudomány mint önálló diszciplína elméleti hátterének felvázolása, kutatási eredményeinek alkalmazása. A cikk az elméleti hátteret, valamint a nyelvi és kulturális távolság bemutatását kö- 
vetôen tematikus csoportokba rendezve tárgyalja a kérdéses szöveg-/szemelvény típusokat: szerepelnek benne a táncpedagógus képzéshez, az intézményi múködéshez és a szakmai előmenetelhez köthető tételek. Utolsó fejezete a nyelvi ellenőrzés szükségességével foglalkozik az alábbi területeken: múfaji terminológia, tantárgyak és szerepek elnevezései; pedagógiai vonatkozások; a múködéshez, fenntartáshoz kapcsolódó szövegpéldák; a szakmai önéletrajzokban előkerülő kérdések; poszt-editálás, forrás- és célnyelvi lektorálás.

Mindezeknek a szövegeknek a fordítása számos fordításetikai és fordítástechnikai kérdést vet fel. Mivel jelen írás nem nyelvészeti szakfolyóirat számára készül, a kérdés elméleti hátterét csak röviden vázolom.

\subsection{A fordítás elméleti háttere}

A fordítástudomány mára önálló nyelvészeti ággá nőtte ki magát, amely több más terület, illetve tudományág érintkezési határán mozog, azok eredményeire támaszkodik. A teljesség igénye nélkül: indulásakor a kontrasztív nyelvészetre, majd a korpusznyelvészetre, a frazeológiára, a funkcionális nyelvészetre, a kulturális- és az interkulturális nyelvészetre, az alkalmazott nyelvészetre, a szociolingvisztikára vagy a modernebb irányok közül a netnyelvészetre és a médianyelvészetre.

A hivatásos fordítóirodák ma már különböző korpuszok alapján terminológiai adatbázisokat hoznak létre, vannak fordítástámogató rendszerek (CAT = Computer-assisted translation), tényleges szövegrészeket tartalmazó fordítási memóriák (TMS = Translation Memory Systems), szövegtárak, gépi előfordító (MT = Machine translation) és nyelvhelyességet ellenőrző programok. A fordító- és tolmácsképzésben jó ideje folyik az olyan szoftverek fejlesztése, amelyek rögzítik a teljes fordítási folyamatot (Hansen, 2013), annak szakaszait, még az azokhoz kapcsolódó fiziológiai megnyilvánulásokat is, így a szemmozgást, mit mennyi ideig szemlél a fordító, a kurzor mozgatását, a szöveg közbeni megállásokat, javításokat, vagyis a párhuzamosan zajló gondolati epizódokat utólag filmszerúen visszanézhetôvé és elemezhetővé teszik.

A fordító-tolmács önálló szakma, legalábbis amennyiben szakképzett múvelőiről beszélünk. Mindazonáltal a hivatásos fordítóknak kétféle megközelítéssel kell szembesülniük. Egyfelől azzal a tévhittel, hogy a munka elvégzéséhez elég jól ismerni a célnyelvet, valamint ennek ellentettjével, miszerint elég adott szakterület képzett múvelőjének lenni. Nem szakmabeliként nem tisztem megállapítani, mekkora a tevékenység presztízse, ugyanakkor egy fordítástudománnyal foglalkozó kutató azt hangsúlyozza, hogy még napjainkban sem egyértelmúen magas, mert amint láttuk is, a közvélekedés szerint bárkiből lehet fordító, ha a helyzet, a szükség úgy hozza (Imre, 2019), azaz nyugodtan fordíthat, hiszen jól tud az adott nyelven.

Jól jelzi a szakma olykor ellentmondásos helyzetét az a tény, hogy a fordítástudomány egyik nagy nemzetközi tekintélye, az angliai születésú, de munkásságát hosszú évtizedek óta a Helsinki Egyetem különbözô nyelvtudományi tanszékein kifejtő Andrew Chesterman egyenesen úgy véli, hogy csakis szakmai képesítéssel rendelkező fordítson, lehetôleg anyanyelvére. Továbbá a fordítóknak-tolmácsoknak az orvosi eskühöz hasonló fogadalmat kellene tenniük, amely a nyelvi-szakmai szempontokon túl jogi és erkölcsi vonatkozásokra is kitérne (Chesterman, 2014). Minden 
kor sajátos velejárója, de a miénknek kiváltképpen csapdája lehet, hogy a fordító mennyire képes kiiktatni saját értékítéletét munkája során.

A fordítástudomány legáltalánosabb elve mindig is azt volt, hogy a fordítás a jelentés átültetésének folyamata. Figyelembe kell venni, hogy minden fordítás alfája és ómegája a szakszavak (terminusok) mint jelentésegységek felismerése, azaz a kötött és így mindenképpen fordítandó elemek felismerése. Ez sajátos készséget igényel, hiszen a terminus jelentése mellett, annak az adott szövegkörnyezetben, kommunikációban betöltött szerepe is ugyanennyire fontos és irányadó (Fóris, 2019). Tamás (2015) megfogalmazása szerint a terminusok felfoghatók a szöveg kulcsfogalmainak, mivel ezek hordozzák a lényegi információ zömét. Érdekes kísérletként egy kiválasztott szövegrészletből kitörölve a terminusokat, láttatja, nélkülük mennyire kitalálhatatlanná válik a szöveg egészének tartalma, lényegi jelentése. A fordító munkája során ad hoc terminológiai tevékenységet folytat.

Amint sejthető, nem elég felismerni, hanem időnként alkotni is kell célnyelvi terminusokat. Minden fordító megtapasztalja, hogy adott célnyelvi terminus híján további megoldást kénytelen keresni, amely lehet a tükörfordítás, a körülírás vagy egy-egy elavult szó felelevenítése. A fordítás tehát legalább három-négy lépést foglal magába: az értelmezést, a felismerést, a megfeleltetést és az alkotást. Mindez

(...) olyan ismereteket és készségeket feltételez, amelyek nem sajátíthatóak el automatikusan a fordítás gyakorlata során. Döntési helyzetek soráról, stratégiák alkalmazásáról van szó, amely tudatos tevékenységet és előzetes elméleti tudást is feltételez. Ezért is tévhit azt gondolni, hogy egy szakember automatikusan kiváló szakfordítóvá válhat. Egy szakterület terminusainak ismerete ugyanis önmagában nem jelent garanciát a terminológia helyes fordítására - ahogyan a kiváló nyelvismeret sem tesz önmagában jó fordítóvá. (Fischer, 2019, p.197).

Vottonen és Jääskeläinen (2018) egyenesen hét ismérvet különít el a fordító definiálásakor, amelyek közül kiemelendő annak a képességnek a megléte, amely alapján képes választásait, megoldásait megindokolni, továbbá önmagát lektorálni és javítani. Koskinen erősen vitatott gondolatsora a fordítóvá, tolmáccsá válás lépcsőfokait mutatja be, miként válhat valakiből szervezett képzés nélkül vagy még inkább annak eredményeként a múfaj hivatásos mûvelője. Megközelítése, amennyiben a két- vagy többnyelvư közegben felnövők csoportját önállóan kezeli, ugyanakkor érdekes fókusz (Koskinen, 2013).

Nem mehetünk el a lektorálás kérdése mellett sem. A lektorálás kétségtelenül beavatkozás, amely mindenek előtt átrendezés, betoldás, törlés, csere vagy megjegyzés hozzáfüzésével szándékozik a célnyelvi szöveget korrigálni és javítani (Robin, 2018). Mára már egyenesen minőségbiztosítási elvárás, hogy minden fordítói szolgáltatás minimális feltétele legyen az ellenőrzés is. Robin amellett, hogy meg is nevezi a vonatkozó jogszabályi helyet (Robin, 2015, 2018), arról is beszámol, hogy nemzetközi kitekintésben is egyre sürgetőbb az igény, hogy a fordítók-tolmácsok mellett hivatásos lektorokat is képezzenek, amely képzés fordítástudományi irányelvei kialakulóban vannak. 


\subsection{A nyelvi és kulturális távolság kérdései}

Nem téveszthetjük szem elől, hogy a 20. század második feléig kizárólag az irodalmi, azaz a múfordítást tekintették alkotó tevékenységnek, a szakfordítást nem (Heltai, 2010). A fordítói húség kérdésköre természetesen elsősorban a szépirodalmi múveknél jön elő, de a pontosság minden területen elvárás. Nyilvánvaló, hogy minden szöveg, legyen az irodalmi mú vagy szakszöveg, mélyen gyökerezik a forrásnyelvi kultúrában és társadalomban, következésképpen magától adódik a kérdés, hogy a fordító az eredeti szöveg konkrét jelentéséhez vagy annak szelleméhez, üzenetéhez ragaszkodjék-e inkább. Barbara Johnson amerikai irodalomtörténész-nyelvész nagyon találó hasonlatát kölcsönözve szemléltethetô ez a feszültség, amennyiben a fordítóról a következőt mondja, „(...) hüségesküje ellenére vagy talán éppen amiatt nem engedelmes házastársnak, hanem hüséges bigámistának kellene tekinteni, aki egyszerre lojális a saját anyanyelvéhez és az idegen nyelvhez. Mindegyiküknek anélkül kell megfelelnie a másik elvárásainak, hogy közben valaha is esélyük lenne a találkozásra" (Johnson, 2014, pp. 371-372).

Arra, hogy néha mennyire nincs esélyük a találkozásra, sarkított példaként álljon itt Szőcs Géza Trianon századik évfordulójára írt prózaversének részlete. A mú a szövegköziség már-már tovább nem fokozható példája, mivel kizárólag egy az egyben, néhol apró részletekben módosított átvételek [félkövér kiemelés tőlem] rendszerbe szervezett összeszerkesztése. Az alkotás kulturális kódja éppen ezért annyira magyar, hogy az vagy abszolút lefordíthatatlanná, vagy élvezhetetlenné teszi, hiszen minden egyes sorát lábjegyzetelni kellene. A sorok zöme kultúraspecifikus reália (Heltai, 2013), történelmi konnotációkkal, szállóigévé vált mondatokkal.

Feketén bólingat az eperfa lombja!

Párizsba beszökött az ősz!

Szent Mihály útján suhant meztelen!

Európa csendes, újra csendes!

Rózsa Sándor összevonja szemöldökét!

A gyertyák csonkig égnek!

Mikor a gyertyák porig égtek, még anyám eljárta a végét!

Kossuth Lajos azt üzente, elfogyott a regimentje!

Próféta lettél, szívem! (Szőcs, 2020, pp. 63-64)

A kulturális szúrő fogalmát House vezette be, azaz a kognitív és szocio-kulturális különbségek felismerésének és alkalmazásának képességét, (amellyel kapcsolatban arról értekezik, hogy megítélése szerint téves nézőpontváltás következtében a szöveg alapú megközelítés mind jobban tolódik a célközönség-orientált fordítás felé (House, 2015). Amennyiben a fordító a kulturális távolság csökkentését tartja szem előtt, úgy honosításról, ha a különbségek érzékeltetéséről, a távolság fenntartásáról van szó, idegenítésról beszélhetünk (Klaudy, 2018).

Kifejezetten nyelvi szempontokat nézve a magyar - idegen nyelv viszonylatban az esetek zömében a fordítás nehézségeinek elsődleges oka, hogy a két érintett nyelv ún. barátságtalan nyelvpár (Klaudy, 2017). Ez azt jelenti, hogy mivel tipológiailag eltérő csoportba tartoznak - a magyar agglutináló, az angol flektáló, egyre erősödő 
izoláló vonásokkal -, számtalan eltérő morfológiai, szintaktikai, szórendi, szóképzési stb. jellegzetességgel bírnak. ${ }^{1}$

\section{TAPASZTALATOK A TERMINOLÓGIA ÉS A LEKTORÁLÁS TERÉN AZ MTE ANYAGAINAK FORDÍTÁSAKOR}

\subsection{Tánc és képzés}

A tánc mint múvészeti ág olyannyira szerteágazó, hogy szakiránytól függően alakult ki hazai terminológiája. Nem kell magyarázni, miért használ mindmáig francia kifejezéseket a klasszikus balett. A magyar néptánc mint hungarikum kezelendő, nincs, nem is lehet nyugat-európai megfelelője, így szakszókincsének idegen nyelvre átültetésénél a terminológia-alkotás (pl. karikázó - girls' circle dance) elkerülhetetlen. A múfaji sokszínûség magával hozza, hogy adott terminus jó az egyik területen, de nem alkalmazható egy másikra. (Pl. "Corps de ballet” a balett esetében a tánckar nemzetközileg ismert megfelelője, de a terminus második elemét nyilvánvalóan el kell hagynunk, esetleg mással helyettesítenünk a többi múfaj esetében.) Magyar sajátosság lehet további különbségek érzékeltetése, amelyeket az angol nem jelöl, azaz furcsa módon ugyanaz a terminus jelölhet kétfélét is: a társastánc és a versenytánc fordítása egyaránt ballroom dances. Ugyanakkor, ha az előbbit tánciskolában táncolják, akkor social dance, az utóbbi pedig értelmezhető dance sport-ként is. A látványtánc kifejezetten magyar terminus, amelyet, jobb nem lévén, show dance-nek lehet fordítani.

Az MTE-n, az MTE kiadványaihoz kapcsolódva vagy más kiadóknál jelentős, ráadásul kétirányú fordítói-terminológiai tevékenységet folytattak nyelvtanárok és más szakemberek, mindenek előtt Vályi Rózsi, Fuchs Lívia, Galamb Zoltán, Melis Béláné, Horváthné Bánky Dóra, Benyő Hedvig, Urbán Mária, Mika Zsuzsanna, Dienes Gedeon, Jeszenszky Endre francia, angol, német és orosz nyelvből vagy nyelvre. Tevékenységük felöleli a klasszikus balett teljes módszertanát, a társas- és versenytáncok, a koreografálás terminológiai magyarítását, a tánctörténet egyes fejezeteit, a dzsessz-táncot.

Az említett kiadványok, szöveggyújtemények, előadások, szószedetek, fordítások elsősorban a múfaji, a táncmódszertani és a múkritikai terület feldolgozásai, emellett az alkotó folyamatoknak, a színpadi jelenlét leírásának a szókincsét honosították meg.

Egy-egy szakterület évtizedek alatt megalkotott, kialakult táncterminológiája a szakma számára ismert, különböző formában nyomtatásban is megjelent. Mind-

\footnotetext{
${ }^{1}$ Az érthetôség kedvéért a nyelvek három fó típusa: az agglutináló (= ragasztó/toldalékoló) nyelvek, amelyek új nyelvtani funkciót vagy új jelentést képzők, jelek, ragok segítségével fejeznek ki. Egyetlen szó, amelyet angolra egész mondattal lehet csak lefordítani, a meg-tánc-ol-tat-hat-ná-l-ak tartalmazza a következố elemeket: rezultativitást kifejező igekötô + fônév + fônévből képzett ige + múveltetô képzô + ható képzô + feltételes mód módjel + egyes szám második személyt jelölő elem, jelen esetben tárgy, (azaz 'téged') + jelen idő, egyes szám első személyú alanyt ('én') jelölő igei személyrag, határozatlan (alanyi) ragozásban. A flektáló (= hajlító) nyelvek a tômagánhangzó megváltoztatásával fejeznek ki grammatikai funkciót vagy új jelentést. Pl. az angol, német rendhagyó/ erős igék a múlt időt, particípiumot: drive, drove, driven. Az izoláló nyelvekben (ld. modern kínai) gyakorlatilag nincs alaktan, pl. ige- és fơnévragozás, ezért a szórendjük szigorúan kötött. Az angol megindult a típusváltás útján, mert mára az egyes szám harmadik személy jelen idő kivételével teljesen eltứnt az igeragozás, a névszóragozás emlékét pedig csak a személyes névmások ragozott alakjai őrzik (me, with him/her, from us, about them.)
} 
azonáltal a kritikák, múelemzések, tanulmányok, interjúk vizsgálata alapján úgy tűnik, nyelvtanár elődöm nem véletlenül fogalmazott úgy, hogy “(...) a tánc szakirodalmának nem létezik magyarul szakszótár alaposságú, kodifikált nyelvi rendszere, ezért mindenek fölött a fordítói kreativitás függvénye a terminus technicusok átültetése." Az általa vizsgált korpusz alapján azon sem csodálkozhatunk, hogy “(...) csak részben megoldható feladat egy nonverbális múfaj jellegzetességeit verbalizálni, azaz szövegszerú formába átültetni." (Benyő, 2009, pp. 71-73).

\subsection{Oktatott tárgyak elnevezése és színpadi szerepek}

Az Egyetemen oktatott számos tantárgy nevének fordításakor találhatunk csak az MTE kínálatában szereplő, tánc-specifikus stúdiumokat, amelyek némelyike értelemszerúen csak adott táncmúfajhoz köthetô (ld. repertoár, spicc, mozgásbiológia, táncmú elemzés, táncjelírás, viselettörténet, történelmi társastánc, koreológia stb.)

A táncmúvészet nemzetközi mozgástere és a mára például az operajátszásban meghonosodott gyakorlat, mely szerint a darabokat az eredeti nyelven éneklik-játszszák, itt is jó minta lehet. A fordító feladata tehát megkeresni, hogy adott szerep (zenemú, darab) milyen nemzetiségú szerző, koreográfus mûve, figyelve egyúttal a cirill betûs névátírásnak az angolban érvényes szabályaira, amelyek a magyar szokástól lényegileg különböznek. Továbbá ellenőriznie, és ha szükséges, javítania kell a darabok, szerepek nevét, főleg helyesírását az eredeti nyelven, legyen az spanyolul, franciául, oroszul. Ezen a téren elsősorban a kortárs darabok eredetének kinyomozása okozhat gondot, illetve annak eldöntése, ha van magyar fordításuk (pl. József és a Színes Szélesvásznú Álomkabát), akkor a pályakép ismertetésében melyik, esetleg mindkét nyelven szerepeljen-e.

\section{NÉHÁNY PEDAGÓGIAI VONATKOZÁS}

A járvány miatt valamennyien hiányoljuk a kontakt (személyes, jelenléti) órákat, amelyek furcsa módon angolul contact hour-nak mondandók, annak ellenére, hogy az angol hour időegységet, időtartamot jelöl, nem pedig tanórát (lesson, class). Nem kevés odafigyelést igényel, amikor nyelvtanárként kezdő csoporttal gyakoroltatjuk a magyar óra szó 4-5 lehetséges, de más-más jelentést kifejező angol megfelelőjét, és akkor itt egy terminus, amelyik minden tankönyvi szabályt felrúg!

A hazai iskolai gyakorlatból jól ismert, ezért a nem pedagógus foglalkozásúaknak is nyilvánvaló, mit jelent a fogadóóra, a vizsgatanitás, a hospitálás. Ezen terminusok némelyikének lehetséges az értelmező körülírása (office hours for consultation, teaching praxis exam). Ugyanakkor a magyar iskolatörténet latinos hagyománya mégsem hatalmazza fel arra a fordítót, hogy az angolban is - egyébként a szókincs igen jelentős százalékát kitevő - latin eredetú szavakat használjon, ha az azonos forrásnyelvi jövevényszó a két nyelvben más irányba fejlődött, ezért jelentésük, konnotációjuk ma nagyban eltér. A hospital-hospitál szópár kétségtelenül hamis barát (faux-amis), vagyis hasonló alakú, de más jelentésú. A magyarban az iskola- és óralátogatás a latin hospes vendég szó származékának tekinthetô, hiszen a tanárjelölt adott iskolában, osztályban vendégként van jelen. Angolul azonban mindjárt a latin szó továbbképzett formája, a hospitale, az angolba rövidüléssel átkerült hospital alak jut az anyanyelvi olvasó eszébe, amely ugyan eredetileg jelenthetett vendégházat is, 
mégis az ispotály (ugyanabból a szóalakból!), kórház jelentés állandósult. Az eredeti jelentést az angolban csak a vendégszeretet/ hospitality főnév és a vendégszerető/ hospitable melléknév őrizte meg, vagyis igei származéka nincs. Marad tehát itt is a magyarázás: - újfent két latin eredetú szóval - iskolai, órai megfigyelés (school/classroom observation) lesz a hospitálásból.

A pedagógiai szakirodalomban és ezért az egyik fordítandó tanulmányban is találkozhattunk a kétszeresen kivételes, ill. kétszeres (v. kettốs) kivételesség kifejezéssel, amely az egyfelől tehetséges, de ugyanakkor szociális hátterük miatt hátrányokkal küzdő diákokat jelöli. A cikk szerzője következetesen ragaszkodott ahhoz, hogy ezt twice exceptional(ity) formában szokás használni, holott itt nem kétszeri, hanem kétszeresen különleges helyzetról van szó, azaz a two-fold vagy a dual tûnne helyesnek. Amennyiben kialakult terminusról van szó, nincs helye a vitának, ha egyedi terminusalkotás, ismételten képzett lektori szemre lett volna szükség.

\section{MỨKÖDTETÉS, FENNTARTÁS}

\subsection{Jogi szövegek}

Mivel a jogi szövegeket rendszerint jogászok fordítják, továbbá a területnek saját szakirodalma van, ez a rövid kitérő mindössze azt kívánja illusztrálni, milyen csapdákat rejt az ilyen fordítási feladat. A szerződések természetesen jogi szakkifejezések sokaságát használják, amelyek fordításához szerencsére rendelkezésre állnak a jogi szótárakon kívül olyan példatárak is, amelyek az adott terminust eredeti szövegekben, azaz szövegkörnyezetükben magyarázzák. Mivel azonban a jogi nyelv minden országban saját hagyományokkal rendelkezik, így bele sem szabad kezdeni még az olyan, látszólag könnyen áthidalható fordulatok, mint „,a szerződő felek a dokumentumot, mint akaratukkal mindenben megegyezőt írják alá" automatikus fordításába sem. Ez az angol tagmondat szó szerint visszafordítva a következőképpen hangzik: , amint ugyanez lévén teljes kifejezése az ő akaratuknak, az aláíró felek aláírják a dokumentumot.” További példák: „,a szerződést határozott időre kötik” szó szerint: „,a megállapodás idejét fix időtartamúnak szerződik” vagy az „indokolás nélkül” kifejezés nem más, mint „bármely vonatkozó ok nélkül”.

\subsection{Kollégiumi házirend}

Külön pontban tárgyalom a kollégiumi házirend jelentette kihívásokat. A szöveg félhivatalos jellegéból adódóan tartalmaz szakkifejezéseket, de a fő gondot ismét a nyelv- és kultúra-specifikus jelenségek okozták. Továbbá mivel hosszú oldalakon át sorakozó szabályokról, lehetséges büntetésekrôl van szó, nem lett volna szerencsés az angolban nem létező elemeket mindig körülírással fordítani és ezzel tovább növelni az amúgy is nagy terjedelmet.

Szakszótárak segítségével ellenőrizhető, hogy mi a létszámellenốrzés (bár gyanítom, inkább a katonaságnál használt terminust találtam), mi a közös használatú terek, a munkabiztonsági és túzrendészeti szabályok megfelelője. Másutt viszont a bevett megoldások valamelyikéhez folyamodtam (Horváth, 2019). Magyarázó körülírás a szilencium mint csöndes idô, illetve csöndes tanulási idố, mivel a szilencium-silence is hamis barátok, továbbá a honosítás, azaz a kulturális távolság csökkentése volt a cél. 
Másutt elavult régi szó felelevenítését alkalmaztam (kimenố mint a kolostori rendtartásokban engedélyezett latinos exeat, azaz eltávozás. Azóta találtam rá egy angol bentlakásos iskola szabályzatában a modernebb és lényegesen egyszerúbb eltávozás (= leave) szóra. Ez a példa rávilágít az idő tényező fontosságára: mivel a határidő szorított, nem biztos, hogy akkor a legjobb megfelelô került a szövegbe.

\section{A TÁNCMÚVÉSZ ÉS TÁNCPEDAGÓGUS ÉLETRAJZOK FORDÍTÁSÁNAK JELLEGZETES PROBLÉMÁI}

\subsection{Intézmények}

Elfogadott szabály, hogy egyesületek, szervezetek, intézmények nevének fordításánál az adott intézmény saját maga által hivatalosan használt nevét kell átvenni, annak ellenére, hogy nyelvileg más vagy több megoldás is létezne. Tipikus esete ennek, amikor a név birtokviszonyt tartalmaz: pl. Magyar Táncmúvészek Szövetsége, amelyet elvileg fordíthatnánk Hungarian Dance Artists' Association-nek, de az angol szórend és a bevett forma az Association of Hungarian Dance Artists.

A köznyelvben csak Honvéd Kórháznak emlegetett intézmény hivatalos magyar neve: Magyar Honvédség Egészségügyi Központ, amely nevet szintén lehetne minden egyes elemével fordítani, ám a hivatalosan használt angol verzió mindössze a Hungarian Military Hospital. Az Oktatási Hivatal magát Education Authority-ként fordítja, annak ellenére, hogy a főnév egyes számú alakja inkább „hatalom/tekintély/fennhatóság" jelentésben használatos, a hivatalhoz jelentésben közelebb álló hatóságot a többes szám fejezi ki. Talán szerencsésebb lett volna a hivatal szónak más megfeleltetést találni. Itt azonban az említett okokból nincs mérlegelési lehetőségünk.

Ha a kérdéses intézménynek van angol nyelvú honlapja, ahol az általa hivatalosnak tekintett nevet megtalálhatjuk, nyert ügyünk van. A helyzet azonban ennél gyakran bonyolultabb. Számos testület magyar és angol nyelvú honlapja ugyanis jelentősen eltér egymástól, akár felépítésükben is. Az idegen nyelvú oldalak többnyire csak a külföldieknek is releváns információkat tartalmazzák, a pályázati, együttmúködési lehetőségeket, képzési kínálatot és ritkábban mutatják be a teljes szervezeti felépítést.

Így ütközünk bele abba, hogy pl. a Magyar Tudományos Akadémia (MTA) angol nyelvư oldalán az Osztályokból tovább léphetünk a Tudományos Bizottságokig, de azon belül már csak, a mi esetünkben fontos Néprajztudományi Bizottságig jutunk el. A Tánctudományi Munkabizottságig mint állandó Al-és Munkabizottsághoz már nem, következésképpen az utóbbiak idegen nyelvú megnevezéseit sem találjuk itt meg. Ilyenkor nem marad más hátra, a kérdéses helyen tagsággal, funkcióval bíró kolléga segítségét kell kérnünk. Gondot jelent az MTA köztestületi tagja reáliának az átültetése idegen nyelvre, annál is inkább, mert a nyugat-európai tudományos élet gyökeresen más elvek mentén szerveződött, mint a magyar és adott esetben a tudományos akadémia mint egységes intézmény is teljesen hiányzik. (Németországban az egyetemi városok hoznak létre civil szervezetként múködő és külön díjazást nem folyósító tudományos akadémiákat.) 


\subsection{Elismerések, kitüntetések}

A hivatalos állami kitüntetések fordítását több tényező is nehezíti. Legelőször is magyarul utána kell járni, hogy egy korábban adományozott kitüntetés ma minek felel meg, azaz hogyan lehet fordítani. Több díj megszúnt a rendszerváltozással, újakat alapítottak vagy korábbiakat átneveztek. Az állami kitüntetéseknek általában van polgári és katonai fokozatuk, ezek angol megfelelőit jó esetben megtaláljuk ide vonatkozó szakmai oldalakon, de azt nem dönthetjük el, hogy ezek mennyire megbízhatóak. Itt tartozom köszönettel a Köztársasági Elnöki Hivatal Főigazgatójának, amiért munkámhoz megküldte a kitüntetések ma használt hivatalos fordítását.

A laikus fordító elsőre visszahőköl az olyan többszörös birtokviszonnyal terhelt megfeleltetések láttán, mint pl. a Magyar Köztársasági Ezüst Érdemkereszt fordításaként használt Silver Cross of Merit of the Republic of Hungary. A mai elnevezés egyszerüsödött: Magyar Ezüst Érdemkereszt (Silver Cross of Merit of Hungary), hiszen az államforma elnevezése is rövidült. Ugyanakkor mégis a bonyolultabb szerkezetet tartottam meg, ha a kitüntetés adományozásának idején az ország neve még $M a$ gyar Köztársaság volt (ld. a sokat emlegetett fordítói döntési helyzeteket). Ugyanez a helyzet bizonyos múvészeti díjak esetében is: a Magyar Köztársaság Érdemes Müvésze napjainkra Magyarország Érdemes Müvésze díjra módosult.

A kifejezetten helyi, mert sajátosan magyar és a csak egyes szakterületen odaítélt táncmúvész díjak fordítása az életrajzokban szerepel, hiszen fontos állomása egyegy mûvész pályájának és visszajelzés a külföldi olvasónak is. A balettmúvészeknél rendszerint olyan kiemelkedő személyiségekről neveztek el kitüntetéseket, hogy ezek nemzetközi viszonylatban is önmagukban elegendőek és érthetők (Fülöp Viktor ösztöndij, Lórinc György dij.) A néptáncosok esetében azonban az elismerést le lehet fordítani, de a couleur locale ismerete nélkül a külföldi olvasó még így sem feltétlenül fogja érteni, mi is az aranysarkantyús, az ezüstpitykés vagy a gyöngygalléros táncos. Ezek fordítása mellett zárójelben meghagytam az eredeti elnevezést is a visszakereshetôség kedvéért.

Helyi, azaz városi, önkormányzati kitüntetésnél elegendőnek ítéltem a díj lényegi fordítását, feltüntetve, hogy azt egy-egy település(rész) adományozta: pl. Pro urbe, XY várostól/kerülettől. Az elkészült fordítások jóváhagyásakor mégis előfordult, hogy az érintett visszatette adott budapesti kerület nevének szó szerinti fordítását is a díj után, ami meglehetôsen mulatságosan hangzik angolul, azon túl, hogy semmilyen információt nem hordoz a kívülálló számára. Itt szándékosan más kerületet említek: Angyalföldet fölösleges Angels' Land-nek mondanunk, mert nem tudunk várostörténeti tanulmányt csatolni a városrészek kialakulásának és elnevezésének megértéséhez. Áthidaló megoldásként idézőjelben meghagytam a név fordítását kiegészítve azzal, hogy az egy kerület neve. Itt tehát részben igazodtam a megrendelő elvárásához, vagyis ismét fordítói döntésre kényszerültem. Klaudy Kinga elemzései szerint (2018) a nyelvi és kulturális aszimmetriákból eredően a fordítási múveletek is aszimmetrikusak, inkább az explicitálás felé hajlanak, mint a fentiekben például a betoldás alkalmazásával. 


\subsection{Egyetemi titulusok}

Az egyetemi címek a mi esetünkben gyakran találkoznak a táncmúvésznek mint tanárnak a besorolásával. Így vannak adjunktusok, docensek, de természetesen mestertanárok, müvésztanárok és nem mellékesen egyetemi, sőt fóiskolai magán-és címzetes egyetemi tanárok is. Az első csoporthoz létezik egy minisztériumi szójegyzék (NEFMI, 2005) (senior lecturers, associate professors stb.), a második kategóriát a korábbi évek tapasztalata és a belső szokás alakította ki (master, artist teacher), a legutolsó csoportnak azonban utána kell olvasni a szakirodalomban. Nem kevés fejtörést okoz az is, hogy a területi nyelvváltozatokban, azaz a brit és az amerikai angolban eltérô az egyetemi címek fordítása (Milinković, 2019). Maradva az Európában bevett terminusoknál a magántanárra az affiliated professor-t, míg a címzetes egyetemi tanárra az honorary professor-t használtam. Mielőtt kényelmesen hátra dőlnénk: a magántáncos természetesen nem affiliated, de nem is private dancer, hanem egyszerúen soloist, ha elsố magántáncos, akkor first soloist.

Egy-egy hivatalos helyről származó szószedet is tartalmazhat megkérdőjelezhetô információt, így az imént említett minisztériumi útmutató is. Feltétlenül kényszer-szülte megoldásnak látszik a felsőoktatási titulusoknál használt főiskolai beosztások listája, amennyiben egy-az egyben az egyetemieket veszi át, kiegészítve a college előtaggal. Angol nyelvterületen értelmezhetetlen a college professor, college senior lecturer (fóiskolai tanár, fóiskolai adjunktus) és társai. Ugyanis Nagy-Britanniában a college a régi értelemben vett kollégium (ld. Sárospataki/Nagyenyedi Református Kollégium) rokona, általában egy-egy egyetem ernyőszervezetén belül a tényleges szakirányú képzést biztosító számos college valamelyike (ld. University of Oxford, Trinity College). Az USA-ban is hasonló a helyzet, a college vagy a brit jelentésben vagy bizonyos egyetemek (pl. üzleti képzésú) megnevezésére használatos, ennyiben közelít a magyar terminushoz.

\section{ELŐFORDÍTOTT VAGY GÉPI FORDÍTÁSÚ SZÖVEGEK POSZT- EDITÁLÁSA, A FORRÁSNYELVI SZÖVEGEK LEKTORÁLÁSÁNAK KÉRDÉSE}

\subsection{Poszt-editálás}

Szinte mind közül ez bizonyult a legnehezebb feladatnak. Egyrészt ezek a szövegek terjedelmes és különféle szaknyelveken írt cikkek. Másrészt azonos anyanyelvûekként a szerző és a fordító azonos nyelvi logikát követ. Továbbá a szerzők valószínúleg gépi fordítást nem a teljes cikküknél, csak annak számukra megoldhatatlan akadályt jelentő részeinél használnak, a többit maguk fordítják le. A lektorálás hiányát leginkább az olyan esetekben tapasztalja meg a fordító, amikor ismeri adott célnyelvi szó, szótő eltérô származékait, azok jelentésével tisztában van, de használatuk helyességét nem tudja megítélni. A terminológia ugyanis gyakran egyáltalán nem logikus. Így jött elő a szakrális tánc fordításánál a két rokon szóalak: sacral és sacred. A köznyelvben az utóbbi a profán ellentéte, azaz szent jelentésû. A múvészetek (pl. zene, költészet), így a tánc esetében mégis ezt kell használni, akkor is, ha magyarként a miénkkel azonos etimológiájú sacral tûnne jónak.

Ezért lenne szükséges, hogy ha már (anyanyelvi) lektor nem is, legalább több átolvasó, felülvizsgáló lássa a fordítást. A nyelvtani hibákat könnyebb észrevenni, 
de a szintaxis, a szórend szempontjából a sokszor romlott nyelvállapotú fordításban vissza kell fejteni a gondolatsort a magyar eredeti alapján ahhoz, hogy korrigálni lehessen az idegen nyelvû́ változatot. Nyilvánvalóan a szerző nyelvtudásától függ, mennyire sikerül jól fordítania, nem filológiai előképzettségúektől nem is várható el, hogy a gépi fordításban felajánlott szinonimasorból ki tudják választani a nyelvileg megfelelőt. (Olyan esetekben, mint az iskolai ünnep(ség) nem lehet a kézenfekvő school holiday-t meghagyni a szövegben, mert arról automatikusan minden anyanyelvi beszélőnek az iskolai szünet, a vakáció jut eszébe.)

\subsection{A forrásnyelvi szövegek lektorálásának kérdése}

" «Szép Szó» magyarul nem fölcicomázott kifejezést, hanem testet öltött érvet jelent. A szép szó nem csak eszközünk, hanem célunk is." (József Attila, 1936)

A hivatalos belső anyagok fajtáiról már sok szó esett. A legtöbb munkát azoknak az anyagoknak a fordítása jelentette, amelyeket magyar nyelvi szempontok alapján is érdemes lett volna előzetesen megszû́rni. A következő részletek megmutatják, miért lehet szükség anyanyelvi lektorálásra is.

Pályázati anyagok nevében gyakran szerepelnek olyan túlterhelt bóvített mondatok, amelyeket ilyen formában jobb lett volna elkerülni, bár ez nem a pályázó felelőssége. Beláthatjuk, milyen magyartalan és milyen nehéz fordítani az ehhez hasonló tételeket: „Módszertani fejlesztések - A KKK-ban és a munkaerőpiaci szereplők által meghatározott kompetenciák az oktatásmódszertan, tananyagfejlesztés területén való érvényesítési lehetőségeinek áttekintése, a kompetencia mérések eredményeinek beépítésének módszertani kidolgozása."

A következő részletben a helytelen szegmentálás, a halmozás, a hiányzó vagy rossz helyen szereplő állítmány teljesen követhetetlenné tették a gondolatmenetet. Feltétlenül eredményként értékelendő, hogy a szerző a lektorálók javaslatait figyelembe véve korrigálta az idő szúkében alaposan át nem nézett elsố magyar szövegváltozatát, így ilyen rossz példák, mint az alábbi mondat egyáltalán nem maradtak a tanulmányban. „A projekt SWOT analízise szerint a csoport egyik erőssége szakemberek sokoldalúsága is hozzáadott értékként jelent meg a múvészetterápiás oldal és a szervezési készségek, a kreatív potenciál; egyszerre volt jelen a szociális érzékenység, emellett több esetben a logisztikai nehézségeket áthidaló rugalmas problémamegoldó készség, rezíliens készségek is a projekt megvalósulásának támaszai voltak." (Ebben a formában meg nem jelentetett kézirat.)

Felfedezhetünk divatjelenségeket is: adott terület legfrissebb szakirodalmában olvasott, konferenciákon hallott idegen szavak, felkapott kifejezések (fúzió, trend, flow, valaminek a világa) köszönnek vissza olyankor is, ha ott a bennfentesség érzékeltetésén kívül mást nem közvetítenek. A fordítás mindig tükröt tart a forrásnyelvi szövegnek: ha bármilyen egyszerúen is megpróbáljuk saját magunk idegen nyelven összefoglalni a mondandónkat, érzékelni fogjuk, mi fölösleges, mi a töltelék szöveg, a tudományosnak tưnő, de inkább nehézkes és a megértést gátló elem benne. Az angol mondatszerkesztés amúgy sem bír el három bekezdésnyi körmondatokat. A fordító ilyenkor darabol, átrendez, értelmez. Magyar nyelvi korrektor minden bizonnyal értelmezést kért volna, majd átfogalmazta volna az alábbi bekezdést is (a múfajokat szándékosan hagytam ki): “(...) A társ fogalma, az együttmúködés szabályai a 
különböző improvizációs feladatok segítségével létrejött Flow érzésen keresztül a zene és a mozgás együttes lüktetésével a (...) táncok könnyedén, szinte észrevétlenül beépülnek a táncosok már technikailag tudatosan felépített mozgáskultúrájába, felszabadulnak, önfeledtebben és bátrabban fejezik ki érzéseiket."(Tervezett ismertetô.)

Az említett három példa szemlélteti, mikor kell a fordítónak beavatkoznia és változtatnia a szövegen. Mossop a gyakorlatban jól hasznosítható iránymutatása szerint (2019), ha az érthetôséget a rossz fogalmazás, a nyelvtani ellentmondások nehezítik, ha nincs logikai kapcsolat a forrásnyelvi anyag adott szakaszának tagmondatai között, célszerú a sorban következő tagmondattal új bekezdést kezdeni. Más esetekben azonban elkerülhetetlen a szerzô megkérdezése és közlési szándékának tisztázása (ld. második példánknál). “Általában a jelentésnek már az elsô, normál tempójú olvasáskor világosnak kell lennie. (...) Ha az eredeti anyag nem gördülékeny, az nem igazolhatja a célnyelvi fordítás nehézkességét." (Mossop, 2019, p. 143)

\section{KONKLÚZIÓ}

A cikkben szereplő példák válogatás eredményei, amelynek célja, hogy az olvasó kívülállóként is megérthesse a fordítás mibenlétét, összetettségét. Az elmúlt néhány év szövegei adott időszak lenyomatai is, amelyek betekintést adnak az intézmény belső életébe és a táncos szakma bizonyos aspektusaiba. Természetesen nem fednek le minden szakterületet. Mivel folyamatosan keletkeznek fordítandó szövegek, amelyek újabb kérdéseket hoznak a felszínre, mindenképpen üdvözlendő a tervezett fordítói munkacsoport létrehozása. Tanszékünk tervez egy olyan kiadványt, amely adatbázisként tartalmazhatná a táncos és az eddig szükségesnek bizonyult összes többi vonatkozó terminológiai jegyzet, könyv, cikk, honlap stb. lelóhelyét. Ugyanígy alapvető fejezete lehetne a már rögzített glosszárium(ok) áttekintése, kiegészítése, akár megjegyzések hozzáfúzése a vitatható elemekhez, (például a divattánc-fashion dance megfeleltetés, az angol nyelvterületen bevett commercial dance helyett). Ennek a kis segédletnek az összeállításában a kiindulópontot a kollégák tapasztalata és tudása képezheti.

Nevek felsorolására jelen keretek között nincs mód, de itt mondok köszönetet valamennyi megkeresett kollégámnak, a szakterületek jeles képviselőinek javaslataikért, nélkülözhetetlen segítségükért.

Utolsó megjegyzésként: ennek a cikknek a megírásával alaposan föladtam a leckét saját magamnak, hiszen a Tánc és Nevelés címú folyóirat angol változata számára le is kell majd fordítanom.

\section{Irodalomjegyzék}

A felsóoktatásban gyakran használt kifejezések angol megfeleltetése. (2005, August 15). NEFMI. http: / / www.nefmi.gov.hu/ felsooktatas/ dokumentumok/ felsooktatasban-gyakran

Benyő, H. (2009). "Széles pillanatok". A táncnyelv fordítási problémái. In A. Németh, R. Major, K. Mizerák, \& P. Tóvay-Nagy (Eds.), Táncmúvészet és tudomány I. Hagyomány és újitás a táncmüvészetben, a táncpedagógiában és a tánckutatásban (pp. 69-74). Magyar Táncmúvészeti Fớiskola. http:/ / mte.eu/wp-content/uploads/2019/08/2007-1.pdf 
Chesterman, A. (2001). Proposal for a Hieronymic Oath. The Translator, 7(2), 139-154 https: / / doi.org/10.1080/13556509.2001.10799097

Fischer, M. (2019). A terminológiai kompetencia fejlesztési lehetőségei, különös tekintettel a terminusok felismerésére. In Sz. Szoták (Ed.), Diszciplinák találkozása. Nyelvi közvetítés a XXI. században (pp. 197-210). Országos Fordító és Fordításhitelesítő Iroda. https: / / www.offi.hu/offi-akademia/kiadvanyok/diszciplinak-talalkozasa-nyelvi-kozvetites-a-xxi-szazadban

Fóris, Á. (2019). Új tendenciák és módszerek a fordítási folyamatban: a terminológia és a dokumentáció szerepe. In Sz. Szoták (Ed.), Diszciplínák találkozása. Nyelvi közvetítés a XXI. században (pp. 211-219). Országos Fordító és Fordításhitelesítő Iroda. https: / / 150.offi.hu/ sites/ default / files / media/ pdf / 18-\%20F\% C3\%B3ris\%20 $\%$ C3\%81gota.pdf

Hansen, G. (2013). The translation process as object of research. In C. Millár, \& F. Bartrina, (Eds.), The Routledge Handbook of Translation Studies (pp. 88-101). Abington. https: / /gydehansen.dk/ media / 2048/ the-translation-process-as-object-of-research.pdf

Heltai, P. (2010). Lexikai átváltási múveletek irodalmi és szakfordításban. In Zs. Bárczi, \& I. Vančoné Kremmer (Eds.), Margó. Írások a forditásról és a kétnyelvüségról (pp. 123-128). AB-ART.

Heltai, P. (2013). Kultúraspecifikus kifejezések és reáliák. Forditástudomány, 15(1), 32-53. https:/ / webcache.googleusercontent.com/search?q=cache:xXWUCitswfMJ:https: / / ojs3.mtak.hu/index.php / fordtud / issue/ download / 261/125+\&cd $=1 \& \mathrm{hl}=\mathrm{hu} \& \mathrm{ct}=\mathrm{clnk} \& \mathrm{gl}=\mathrm{hu}$

Horváth, P. I. (2019). Hiteles fordítás és terminológia - 1000 szó tükrében. In Sz. Szoták (Ed.), Diszciplinák találkozása. Nyelvi közvetítés a XXI. században (pp. 220-246). Országos Fordító és Fordításhitelesítő Iroda. https: / / www.offi.hu/offi-akademia/ kiadvanyok/diszciplinak-talalkozasa-nyelvi-kozvetites-a-xxi-szazadban

House, J. (2015). Translation quality assessment. Past and present. Routledge. https: / / salahlibrary.files.wordpress.com/2018/10/translation-quality-assessment.pdf

Imre, A. (2019). A fordítók szakmai etikájának kihívásai. Tanulmányok 2019/1 (pp. 147-160). BTK, Újvidék. https: / doi.org/10.19090/ tm.2019.1.147-160

Johnson, B. (2014). Taking Fidelity Philosophically. In M. Feuerstein, B. J. González, L. Porten, \& K. Valens (Eds.), The Barbara Johnson Reader. The Surprise of Otherness (pp. 371-372). Duke University Press. https:/ / doi.org/10.1215/9780822399070025

József, A. (1936). Szerkesztői üzenet. Szép Szó, 1(2). http:// magyar-irodalom.elte. $\mathrm{hu} /$ sulinet/igyjo/setup/portrek/jozsefa/szerkuz.htm

Klaudy, K. (2007). Nyelv és forditás. Válogatott fordítástudományi tanulmányok. Tinta Könyvkiadó.

Klaudy, K. (2018). Az aszimmetria hipotézis kiterjesztése a honosítás/idegenítés dichotómiára. In J. Dombi, J. Farkas, E. Guti (Eds.), Aszimmetrikus kommunikáció - aszimmetrikus viszonyok. A XXVI. MANYE Kongresszus elóadásai (pp. 448-463). Szak Kiadó.

Koskinen, K. (2013). Johdanto: Tampere translationaalisena tilana. In K. Koskinen (Ed.), Tulkattu Tampere (pp. 11-29). Tampere University Press. https: / / trepo.tuni. fi / bitstream / handle / 10024/103246/978-951-44-9048-4.pdf?sequence=1\&isAllowed $=y$ 
Milinković, S. (2019). Translating Degrees and Academic Titles Abbreviations: Challenges and Perspectives. In Sz. Szoták (Ed.), Diszciplinák találkozása. Nyelvi közvetítés a XXI. században (p. 158-167). Országos Fordító és Fordításhitelesítő Iroda. https: / / www.offi.hu / offi-akademia/ kiadvanyok/ diszciplinak-talalkozasa-nyelvi-kozvetites-a-xxi-szazadban

Mossop, B. (2019). Revising and Editing for Translators. Routledge. https://doi. org/10.4324/9781315158990

Robin, E. (2015). A fordító mint lektor. In I. Horváth (Ed.), A modern fordító és tolmács (pp. 35-47). ELTE Eötvös Kiadó. 2015. http://www.eltereader.hu/media/2017/01/Horvath_Modern-ford_READER.pdf

Robin, E. (2018). A Classification of Revisional Modifications. In I. Horváth (Ed.), Latest Trends in Hungarian Translation Studies. Court interpreting, conference interpreting, terminology, audiovisual translation and revision (pp. 155-164). OFFI. https:/ / www.offi.hu/sites / default / files / media / files / horvath_latest_trends_reader.pdf

Tamás, D. M. (2015). A fordító mint terminológus. In I. Horváth (Ed.), A modern fordító és tolmács (pp. 47-66). ELTE Eötvös Kiadó. http:/ / www.eltereader.hu/media/2017/01/Horvath_Modern-ford_READER.pdf

Várnai, J. Sz. (Ed.). (2004). Az Európai Unió Hivatalos Kifejezéstára angol-magyar-francia-német / Official Terminology of the European Union English-Hungarian-French-German. MorphoLogic-SZAK Kiadó.

Vottonen, E., \& Jääskeläinen, R. (2018). Käänäjältä edellytettävän teoreettisen tiedon näkyvyys opetussuunnitelmassa ja reflektoivien loppuesineissä. Electronic Journal of the KäTu Symposium on Translation and Interpreting Studies, 11, 84-97 https: / / www.sktl.fi/@Bin/1910852/MikaEL11_Vottonen_J\%C3\%A4\%C3\%A4skel\%C3\% A4inen.pdf

\section{Szépirodalmi források}

Ady Endre (1906). Párisban járt az ósz. https: / / mek.oszk.hu/00500/00588/html /

Arany János (1851). Családi kör. https: / / mek.oszk.hu/00500/00597/html/v1850-52. htm

Kossuth Lajos azt üzente... [népdal]. (1848-49). http:/ / www.mek.oszk.hu/06200/ 06234/html/nepdalok0020300009.html

Márai Sándor (1942). A gyertyák csonkig égnek. https://pim.hu/archivum/nyugat100/ object.67227F16-A102-4199-835A-8AA7864590EA.ivy.html

Móricz Zsigmond (1942). Rózsa Sándor összevonja a szemöldökét. https: / / mek.oszk. $\mathrm{hu} / 01500 / 01546 / \mathrm{html} /$

Petőfi Sándor(1849). Európa csendes, ujra csendes. https: / / mek.oszk.hu / 01000 / 01006 / $\mathrm{html} / \mathrm{vs} 184901 . \mathrm{htm} \# 03$

Sinka István (1939). Anyám balladát táncol. https://mek.oszk.hu/01000/01006/ html/vs184901.htm\#03

Somogyi Tóth Sándor (1976). Próféta voltál szívem. http: / / legeza.oszk.hu / sendpage. php?rec=li1954

Szőcs, G. (2020). Táviratok jönnek-mennek. In Z. Jánosi (Ed.), Harangokkal írtévszázad 1920-2020. Történelmi elemzések, esszék, szépirodalmi müvek a trianoni békediktátumról és következményeiról (pp. 62-63). Fókusz Egyesület, Írott Szó Alapítvány, Magyar Napló. 